\title{
REPRODUCTIVE INDEXES AND MILK PERFORMANCE OF EWES TREATED WITH DIFFERENT ANTIOXIDANT DURING TRANSIT PERIOD PRIOR TO BREEDING SEASON. Abdel-Khalek, A.E.*; T.M. Ashmawy ${ }^{\star \star}$ and Liza A. Abdel-Rafaa** * Anim. Prod. Dept., Fac. Agric., Mansoura University. \\ ${ }^{\star *}$ Anim. Prod. Res. Instit., Agric, Res. Center, Egypt.
}

\begin{abstract}
Aim of this study was to evaluate the effect of treatment with vitamins A (VA), $C$ (VC) and $\mathrm{AD}_{3} \mathrm{E}$, selenium (Se) or their combination before September mating season, on productive and reproductive performances of crossbred ewes and their offsprings. Total of 72 crossbred ewes (3-4 y of age and $44.19 \mathrm{~kg}$ live body weight, LBW) were used in this study. Ewes in the $1^{\text {st }}$ group (G1) served as a control without treatmant, while those in treatment groups were treated orally with VA (5000 IU/ewe, G2) or injected with $1 \mathrm{ml}$ of $A D_{3} E$ (G3), Se (G4) or VC (G5), or with the same treatments of their combination (G6). LBW of ewes and lambs as well as placental weight (PW) were recorded. Milk yield was individually recorded and milk samples were taken for chemical analysis during $45 \mathrm{~d}$ of the suckling period. Blood samples were collected for determination of progesterone (P4) concentration during 50 postmating in ewe serum, and of concentration of total proteins (TP), albumin (AL), globulin (GL) and cholesterol in lamb serum at weaning. Reproductive indexes including estrus rate (ER), fertility rate (FR), fecundity rate (FCR) and prolificacy rate $(\mathrm{PR})$ were also calculated. Mortality rate (MR) of lambs was recorded at weaning.

Results show that the effect of treatment on LBW of ewes, PW of ewes or LBW of lambs at birth or weaning based on sex of lambs and type of birth, milk yield, milk contents, except fat percent, P4 concentration, and average LBW of lambs at lambing or weaning based on sex and type of birth was not significant. Average PW of all lambs was lower $(P<0.05)$ in $\mathrm{G} 3$ and $\mathrm{G} 2$ than in $\mathrm{G} 1, \mathrm{G} 4, \mathrm{G} 5$ and G6. Milk fat percent increased $(P<0.05)$ in $G 2$ and $G 3(5.04$ and $5.43 \%)$, while it did not differ in G4, G5 and G6 (4.28, 4.62 and 4.29\%) compared with G1 (4.47\%). ER was 0.0, 25 , 33.3, 16.7, 25 and 16.7\% $(\mathrm{P}<0.05)$ during the transit period and 100, 83.4, 91.6, 100 , 100 and $100 \% \quad(P<0.05)$ at the end of breeding season in the treatment groups, respectively. FR was 83.3, 91.7, 75.0, 75.0, 91.7 and $91.7 \%(P<0.05)$, FCR was 125 , 133, 100, 92, 108 and 108\%, and PR was 150, 145, 133, 122, 118 and $118 \%$ in the six groups, respectively. Ewes in $\mathrm{G} 2$ showed the highest $(\mathrm{P}<0.05)$ twin births and the lowest single type $(62.5: 37.5 \%, P<0.05)$ versus an opposite trend in other treatment groups (G3-G6). MR of lambs at weaning was $0 \%$ in $\mathrm{G} 1, \mathrm{G} 2$ and $\mathrm{G} 6$ versus 8.33, 9.10 and $7.69 \%$ in $G 3, G 4$ and $G 5$, respectively. Lambs of $G 6$ showed the highest $(P<0.05)$ concentration of TP, AL, GL and cholesterol.

In conclusion, The treatment with vitamins $A(V A), C(V C)$ and $A D_{3} E$, selenium (Se) or their combination before September mating season improvement the productive and reproductive performances of crossbred ewes and their offsprings.
\end{abstract}

\section{INTRODUCTION}

Oxidative stress is experienced by the living organisms from both exogenous and endogenous sources in terrestrial as well as marine environments (Lesser, 2006). Production of oxidants together with the ability of organisms to respond to oxidative stress is intricately connected to ageing 
and life span (Finkel and Holbrook, 2000). Oxidative stress is involved in the etiology of defective embryo development. Embryo metabolism generates reactive oxygen species (ROS) via several enzymatic mechanisms, which may alter most of cellular molecules and induce developmental block and retardation (Guérin et al., 2001).

In mammals, ROS are essential factors of cell division, differentiation and growth, notably during prenatal stage. The ROS may be produced at early developmental stages, necessitating anti-oxidative defense mechanisms. Free radicals and ROS play significant and diverse roles in reproductive biology (Riley and Behrman, 1991) and have been implicated in fetal dysmorphogenesis, abortions and intrauterine growth restriction (Agarwal et al., 2006). Under normal conditions, the developing embryo is capable of coping with oxidative stress but this may fail under various pathological conditions, leading to embryonic damage (Zaken et al., 2000).

The corpus luteum $(\mathrm{CL})$ at early pregnancy may be rescued from luteolysis through increasing activities of key antioxidant. The $C L$ throughout pregnancy may be linked to ROS generated continuously in the steroidogenically active luteal cells, and may be involved in the maintenance of luteal steroidgenic activity and cellular integrity (Al-Gubory et al., 2004).

It could be hypothesized that antioxidants and oxidative stress may influence the timing and maintenance of a viable pregnancy as threshold levels of female oxidative stress exist, depending on anatomic location and stage of preconception (Ruder et al., 2008). The stress factors induce an inhibition of progesterone synthesis in repeat breeder cows (Rizzo et al., 2007). Seasonal periods of heat stress reduce milk yields and fertility in lactating dairy cows. Heat stress during follicular recruitment suppresses subsequent growth to ovulation, accompanied by decreased $\mathrm{LH}$ receptor level and estradiol synthesis in the follicles (Özawa et al., 2005; Roth, 2008).

The antioxidant function could, at least in part, enhance immunity and increase animal production efficiency (McDowell, 2002). Short term supplementation of $\beta$-carotene to goats may result in enhanced ovarian function and progesterone synthesis (Arellano-Rodriguez et al., 2008). It was reported that vitamin E-selenium injections given before ewe mating significantly increased the incidence of estrus response, fecundity rate and lamb body weight at 60 days of age (Koyuncu and Yerlikaya, 2007). Also, supplementation with vitamin $\mathrm{E}(\mathrm{VE})$ and selenium (Se) may be beneficial in reducing $\mathrm{ROS}$ in dystocia-affected buffaloes in the immediate post-partum period (Sathya et al., 2007).

The dietary and tissue balance of antioxidant nutrients is important in protecting tissues against free radical damage. Vitamins and trace minerals have dual effects: (a) control of metabolic pathways or gene expression and (b) ROS trapping activity. Their deficiency may induce high rates of ROS production resulting in different disorders of gestation (Aurousseau et al., 2006). These deficiencies may also be due to different kinds of stress (McDowell et al., 2007). Feeding calves on VE and/or vitamin C is associated with alterations in the concentrations of other antioxidants (Cusack et al., 2005). 
The aim of this study was to evaluate the effect of treatment with antioxidants such as vitamins $\mathrm{A}, \mathrm{C}$ and $\mathrm{AD}_{3} \mathrm{E}$ and trace mineral such as $\mathrm{Se}$, or their combination during August, before September mating season, on productive and reproductive performances of crossbred ewes. Also, growth parameters, mortality rate and blood parameters of produced lambs were studied.

\section{MATERIALS AND METHODS}

This study was carried out at Sakha Experimental Station, located in the northern part of the Delta, belonging to the Animal Production Research Institute (APRI), Agricultural Research Center, Ministry of Agriculture, in cooperation with Animal Production Department, Faculty of Agriculture, Mansoura University.

Animals:

During August, before September mating season (according to the system of APRI), total of 72 crossbred (1/2 Finnish Landrace $\times 1 / 2$ Rahmani) ewes having 3-4 years of age and averaged $44.19 \pm 0.19 \mathrm{~kg}$ live body weight (LBW) were used in this study. Ewes were kept under similar management conditions and housed in collective pens. Water and mineral salt were permanently available.

Feeding system:

Ewes were fed a basal ration consisting of $25 \%$ concentrate feed mixture (CFM) beside $75 \%$ fresh berseem (FB, Trifolium alexandrinum) during winter feeding (November-April) or 50\% CFM and 50\% berseem hay (BH) during summer feeding (May and June). The CFM consisted of cotton seed cake, linseed cake, yellow corn, wheat bran, molasses, calcium chloride and common salt. Ewes were fed according to NRC feeding requirements (NRC, 2001). The daily feed amounts of $1.250 \mathrm{~kg}$ CFM were offered once daily at 8 a.m. plus $4 \mathrm{~kg} \mathrm{FB}$ or $1.3 \mathrm{~kg} \mathrm{BH}$ were offered twice daily at 11 a.m. and 3 p.m. for each doe. Chemical composition of different feedstuffs is presented in Table (1). The amounts of CFM were adjusted according to the changes of body weight of ewes. The CFM and FB or BH were chemically analyzed according to the methods of AOAC (1990).

Table (1): Chemical composition of different feedstuffs.

\begin{tabular}{|l|c|c|c|c|c|c|c|}
\hline \multirow{2}{*}{ Item } & \multirow{2}{*}{ DM } & \multicolumn{6}{c|}{ Chemical composition (on DM basis) } \\
\cline { 3 - 8 } & & OM & CP & CF & EE & NFE & Ash \\
\hline CFM & 89.85 & 87.77 & 14.42 & 7.18 & 2.42 & 63.78 & 12.54 \\
\hline Fresh berseem & 17.26 & 88.79 & 16.68 & 21.98 & 2.38 & 48.65 & 11.44 \\
\hline Berseem hay & 86.49 & 89.39 & 12.75 & 27.84 & 3.43 & 45.38 & 10.87 \\
\hline
\end{tabular}

CFM: Concentrate feed mixture.

\section{Treatments:}

At middle of August, the experimental ewes ( $n=72$ ) were divided into six groups (12 in each) according to their age and LBW. Ewes in the $1^{\text {st }}$ group (G1) served as a control group without treatment. However, ewes in the $2^{\text {nd }}$, $3^{\text {rd }}, 4^{\text {th }}$ and $5^{\text {th }}$ groups were treated orally with vitamin A (A-VETONE, capsule of $5000 \mathrm{IU}$ of vitamin $\mathrm{A}, \mathrm{G} 2$ ) or injected with $\mathrm{AD}_{3} \mathrm{E}$ (ADEVET, each $1 \mathrm{ml}$ 
contained $100.000 \mathrm{IU}$ vitamin $\mathrm{A}, 20.000 \mathrm{IU}$ vitamin $\mathrm{D}_{3}$ and $20 \mathrm{mg}$ vitamin $\mathrm{E}$, G3), selenium (Tocosel-Forte, each $1 \mathrm{ml}$ contained $150 \mathrm{mg}$ dl-alpha tocopheryl acetate and $1.1 \mathrm{mg}$, sodium selenite, G4) and vitamin C (Sevagi, each $1 \mathrm{ml}$ contained $0.2 \mathrm{~g}$ vitamin $\mathrm{C}$ and $0.2 \mathrm{~g}$ Anlagin, G5). While, ewes in the $6^{\text {th }}$ group were received a combined of oral vitamin A plus injections of vitamin $\mathrm{AD}_{3} \mathrm{E}$, selenium and vitamin $\mathrm{C}(\mathrm{G} 6)$.

\section{Body and placental weights:}

Ewes in all groups were weighed at August, September (breeding season) and post-lambing. Also, placental weight was recorded at lambing. Lambs produced from each group were weighed at birth and weaning according to sex and type of births.

\section{Milking and milk samples:}

During the day of milking, lambs were removed from their dams and allowed to suckle other ewes. During the suckling period, 5 ewes of each group were milked by hand every two weeks. Hand milking was carried out twice at the day of milking (6 a.m. and 5 p.m.). Milk yield was individually recorded and milk samples were taken for chemical analysis. The total milk yield for a ewe and chemical composition of milk at the day of milking was considered to represent average daily milk yield (ADMY) during the previous two weeks $(15,30$ and 45 days of the suckling period), then ADMY and milk composition was calculated for the first 45 days of post-partum for each ewe.

The morning milk from ewes of each breed group cooled at $5^{\circ} \mathrm{C}$ added to the evening milk, well mixed and representative samples were taken. Milk samples were stored at $-5^{\circ} \mathrm{C}$ till analyses for fat, protein, lactose, total solids and solids not fat using Milko-Scan (133B N. Foss Electric, Denmark).

\section{Blood sampling:}

On day 5, 30, 40 and 50 post-mating, blood samples were taken from the jugular vein of all ewes in each group into vacotainer tubes. After clotting, blood samples were centrifuged at $15 \mathrm{~g}$ for $15 \mathrm{~min}$, and then blood serum was separated and stored at $-20^{\circ} \mathrm{C}$ until progesterone (P4) assay.

Quantitative determination of P4 in blood serum was carried out using progesterone radioimmunoassay kit (Catalog No. 1188 manufactured by Immunotech, France). The assay is based on competition reaction (Bojanic et al., 1991). Samples $(50 \mu l)$ were incubated $1 \mathrm{~h}$ with $\mathrm{I}^{125}$ labeled progesterone $(500 \mu \mathrm{l})$, as tracer, in antibody-coated tube. After incubation the liquid contents of the tubes are aspirated and bound radioactivity is measured to determine progesterone in serum using automatic Mini-Gama counter (LKB 1275, USA). The sensitivity of the P4 assay is $0.03 \mathrm{ng} / \mathrm{ml}$, while coefficient of variation is $4.3 \%$ for both progesterone intra- and inter-assay, respectively.

Also, blood samples were taken from 5 lambs of each group at weaning for determination of total proteins (Henry, 1964), albumin (Hill and Weels (1983) and total cholesterol (Rolschlau, 1974) concentrations in blood serum. However, globulin concentration was calculated.

\section{Suckling period:}

After parturition, lambs were allowed to suckle their dams up to reach a minimum age of 8 weeks and a minimum body weight of $11-12 \mathrm{~kg}$ when 
they have been weaned. Newborn male and female lambs produced from each experimental group were kept at the same feeding system of their dams. Lambs were fed according to the NRC (2001) allowances on concentrate feed mixture (CFM) and fresh berseem (FB) up to May 2013 and $\mathrm{CFM}$ and berseem hay $(\mathrm{BH})$ up to the end of the experiment. Mortality rate of lambs was recorded at weaning.

Reproductive performance:

Reproductive traits of ewes in response to different treatment were recorded including estrus rate (ER), fertility rate (FR), fecundity rate (FCR) and prolificacy rate $(\mathrm{PR})$ as the following:

$E R \%=$ No. of ewes showing estrus during season/joined ewes $\times 100$.

$F R \%=$ No. of lambed ewes $/$ joined ewes $\times 100$.

$F C R \%=$ No. of born lambs/ joined ewes $\times 100$.

$P R=$ No. of born lambs /lambed ewes $\times 100$.

(Janadeen and Hafez, 1993)

Statistical analysis:

Data obtained in this study were subjected to statistical analysis using General Linear Models Procedures (GLMP) adapted by SPSS for windows (2004) for user's guide. Duncan Multiple range test of SPSS programme was done to determine the degree of significance between the means at $\mathrm{P}<0.05$.

\section{RESULTS AND DISCUSSION}

\section{Changes in live body weight of ewes:}

Data presented in Table 2 show that the effect of treatment on LBW of ewes in August and September, and post-lambing was not significant. During the interval from August and September, LBW of ewes was higher in G1 than in other treatment groups.

Such result indicated no effect of different treatments on LBW of ewes pre- or during breeding season.

Table (2): Effect of treatment on live body weight (kg) of ewes in August and September, and post-lambing.

\begin{tabular}{|l|c|c|c|}
\hline \multicolumn{1}{|c|}{ Treatment group } & August & September $^{*}$ & Post-lambing \\
\hline G1 (Control) & $44.75 \pm 1.85$ & $47.50 \pm 2.20$ & $47.00 \pm 2.46$ \\
\hline G2 $(\mathrm{VA})$ & $43.25 \pm 1.28$ & $44.91 \pm 1.11$ & $44.87 \pm 2.15$ \\
\hline $\mathrm{G} 3\left(\mathrm{AD} \mathrm{D}_{3} \mathrm{E}\right)$ & $44.83 \pm 1.08$ & $45.75 \pm 1.29$ & $45.33 \pm 1.41$ \\
\hline $\mathrm{G} 4(\mathrm{Se})$ & $42.83 \pm 1.22$ & $44.33 \pm 1.42$ & $43.50 \pm 1.88$ \\
\hline $\mathrm{G} 5(\mathrm{VC})$ & $44.08 \pm 1.27$ & $45.85 \pm 1.59$ & $44.90 \pm 1.29$ \\
\hline $\mathrm{G} 6($ Combination) & $45.41 \pm 0.92$ & $46.58 \pm 0.97$ & $43.33 \pm 1.52$ \\
\hline
\end{tabular}

${ }^{*}$ Breeding season. All group differences are not significant at $P \geq 0.05$.

\section{Placental weight at lambing:}

Results shown in Table 3 revealed significant effect of treatment on average placental weight of ewes at lambing. Only, placental weight of ewes in $G 3$ treated with vitamin $A D_{3} E$ was significantly $(P<0.05)$ lower than that in 
the control group (G1), G4, G5 and G6, but did not differ significantly from that in $\mathrm{G} 2$.

Table (3): Effect of treatment on placenta weight (g) of ewes at lambing.

\begin{tabular}{|c|c|c|c|c|c|c|}
\hline Item & $\begin{array}{c}\text { G1 } \\
\text { (Control) }\end{array}$ & $\begin{array}{c}\text { G2 } \\
\text { (VA) }\end{array}$ & $\begin{array}{c}\text { G3 } \\
\left(A D_{3} E\right)\end{array}$ & $\begin{array}{l}\text { G4 } \\
\text { (Se) }\end{array}$ & $\begin{array}{c}\text { G5 } \\
\text { (VC) }\end{array}$ & $\begin{array}{c}\text { G6 } \\
\text { (Combin.) }\end{array}$ \\
\hline Mean & $512 \pm 51.1^{a}$ & $378 \pm 34.5^{\mathrm{ab}}$ & $310 \pm 52.7^{b}$ & $505 \pm 28.2^{a}$ & $457 \pm 53.4^{a}$ & $496 \pm 45.7^{a}$ \\
\hline \multicolumn{7}{|c|}{ Placental weight (g/ewe) as affected by sex of born : } \\
\hline Male & $533 \pm 36.2$ & $415 \pm 82.1$ & $347 \pm 81.4$ & $542 \pm 37.8$ & $490 \pm 85.1$ & $591 \pm 64.7$ \\
\hline Female & $487 \pm 101$ & $349 \pm 19.7$ & $281 \pm 74.8$ & $468 \pm 18.1$ & $412 \pm 66.5$ & $437 \pm 47.4$ \\
\hline \multicolumn{7}{|c|}{ Placental weight (g/ewe) as affected by type of birth : } \\
\hline Single & $416 \pm 102$ & $312 \pm 0.00$ & $347 \pm 82.1$ & $495 \pm 34.4$ & $386 \pm 46.2$ & $523 \pm 19.8$ \\
\hline Twins & $560 \pm 58.2$ & $397 \pm 41.0$ & $281 \pm 74.9$ & $535 \pm 0.00$ & $600 \pm 111$ & $480 \pm 1.43$ \\
\hline
\end{tabular}

a and b: Means denoted within the same column with different superscripts are significantly different at $\mathrm{P}<0.05$.

The observed reduction in placental weight of ewes treated with $\mathrm{AD}_{3} \mathrm{E}$ was not explained in the literature. However, this reduction was associated with decreasing of lamb body weight produced from ewes in G3, which will be discussed latter in Table (3).

It is of interest to note that the effect of treatment on placental weight of ewes was not significant when placental weight was compared among groups based on sex of lambs and type of births (Table 3). This finding may indicate poor relationship between placental weight of ewes and each of sex of lambs and type of births, regardless treatment.

Milk production:

Results presented in Table 4 revealed insignificant effect of treatment on average daily milk yield of ewes. However, among all milk contents, only fat percent in milk of ewes in G2, G3 significantly $(P<0.05)$ increased as compared to the control milk (G1). Meanwhile, milk of ewes in G4, G5 and G6 did not differ significantly than in G1.

It is worthy noting that ewes in $G 3$ treated with $A_{3} E$ showed the highest milk yield and fat content, indicating the highest fat yield from ewes in this group as compared to other treatment and control groups. Such trend may be due to synergistic effect of vitamins $A, D$ and $E$.

Estimates of the amount of milk produced by lactating ewes provide information for the implementation of optimum management and feeding strategies for ewe and their lambs (Cardellino and Benson, 2002). Generally, milk yield of dairy ewes was affected by number of suckling lambs during pregnancy or lactation (Treacher, 1978), type of birth, single, twins or triplets (Snowder and Glimp, 1991), lambing season (Hamdon, 2005) or lactation period length (Morsy, 2002). 
Table (4): Effect of treatment on average daily milk yield (g) and milk composition of ewes during up to $\mathbf{4 5}$ days of lactation.

\begin{tabular}{|c|c|c|c|c|c|c|}
\hline \multirow{2}{*}{ Treat. group } & $\begin{array}{c}\text { Milk yield } \\
(\mathbf{g} / \mathbf{h} / \mathbf{d})\end{array}$ & \multicolumn{6}{|c|}{ Milk composition (\%) } \\
\cline { 3 - 7 } & 615 & 4.47 & 4.66 & 5.47 & 10.71 & 15.19 \\
(Control) & \pm 0.012 & $\pm 0.507^{\mathrm{b}}$ & \pm 0.253 & \pm 0.664 & \pm 0.500 & \pm 0.832 \\
\hline G2 & 625 & 5.04 & 4.51 & 5.30 & 10.48 & 15.50 \\
$(\mathrm{VA})$ & \pm 0.015 & $\pm 0.960^{\mathrm{a}}$ & \pm 0.497 & \pm 0.470 & \pm 0.928 & \pm 1.497 \\
\hline G3 & 638 & 5.43 & 4.54 & 5.10 & 10.27 & 15.50 \\
$(\mathrm{AD}$ E) & \pm 0.009 & $\pm 0.681^{\mathrm{a}}$ & \pm 0.452 & \pm 0.669 & \pm 0.807 & \pm 1.194 \\
\hline G4 & 614 & 4.28 & 4.48 & 5.20 & 10.28 & 14.60 \\
(Se) & \pm 0.011 & $\pm 0.736^{\mathrm{b}}$ & \pm 0.441 & \pm 0.665 & \pm 0.651 & \pm 1.263 \\
\hline G5 & 615 & 4.62 & 4.45 & 5.59 & 10.68 & 15.27 \\
(VC) & \pm 0.011 & $\pm 0.584^{\mathrm{b}}$ & \pm 0.287 & \pm 0.315 & \pm 0.258 & \pm 0.730 \\
\hline G6 & 613 & 4.29 & 4.28 & 5.66 & 10.63 & 14.71 \\
(Combin.) & \pm 0.013 & $\pm 0.457^{\mathrm{b}}$ & \pm 0.435 & \pm 0.475 & \pm 0.882 & \pm 0.452 \\
\hline
\end{tabular}

a and b: Means denoted within the same column with different superscripts are significantly different at $P<0.05$.

\section{Ovarian and estrous activity: \\ Estrous rate:}

Results presented in Table 5 revealed that ewes in all treatment groups showed estrous activity during the transit period prior to breeding season (16-30 August), while none of the control ewes exhibited estrus signs. Comparing among treatment groups, ewes in $\mathrm{G} 3$ treated with vitamin $\mathrm{AD}_{3} \mathrm{E}$ showed significantly $(P<0.05)$ higher estrous rate $(33.3 \%)$ than those treated with $\mathrm{Se}(\mathrm{G} 4,16.7 \%)$ or with a combination of vitamins and Se (G6, 16.7\%), but did not differ significantly from those in G2 treated with vitamin A or C (25\% for each).

During the $1^{\text {st }}$ half of the breeding season (1-15 September), only ewes in G6 $(75 \%)$ and G4 $(66.7 \%)$ showed significantly $(P<0.05)$ higher estrus rate than in the control ewes (G1, 50\%). However, ewes in other treatment groups did not differ in estrus rate from that in the control (G1). This means that, up to the $1^{\text {st }}$ half of breeding season, ewes in all treatment groups showed higher estrus rate than the control ewes, being 91.7, 83.3, 82.7, 83.3 and $66.7 \%$ in G6, G5, G4, G3 and G2 as compared to $50 \%$ in G1, respectively.

During the $2^{\text {nd }}$ half of the breeding season (16-30 September), the control ewes showed the highest estrus rate $(50 \%)$ as compared to $16.7 \%$ in G2, G4, and G5, and $6.3 \%$ in G3 and G6. Interestingly to recorded that, all ewes (100\%) in G1, G4, G5 and G6 exhibited estrous activity and mated at the end of breeding season versus 83.4 and $91.6 \%$ in G2 and G3, which may suggest inverse effect of vitamin $A$ or $A D_{3} E$ on estrous activity of ewes during breeding season 
Table (5): Effect of treatment on estrus/mating rate of ewes pre- and during breeding season.

\begin{tabular}{|c|c|c|c|c|c|c|c|c|c|}
\hline \multirow{3}{*}{$\begin{array}{l}\text { Treatment } \\
\text { group }\end{array}$} & \multirow{3}{*}{$\mathbf{N}$} & \multicolumn{6}{|c|}{ Ewes showing estrus/mating } & \multirow{2}{*}{\multicolumn{2}{|c|}{$\begin{array}{c}\text { Mated ewes } \\
16 \text { Aug.-30 Sept. }\end{array}$}} \\
\hline & & \multicolumn{2}{|c|}{ 16-30 Aug. } & \multicolumn{2}{|c|}{1 -15 Sept. } & \multicolumn{2}{|c|}{ 16-30 Sept. } & & \\
\hline & & $\mathbf{n}$ & $\%$ & $\mathbf{n}$ & $\%$ & $\mathbf{n}$ & $\%$ & $\mathbf{n}$ & $\%$ \\
\hline G1 (Control) & 12 & 0 & $0.00^{c}$ & 6 & $50.0^{\mathrm{bc}}$ & 6 & $50.0^{a}$ & 12 & $100^{a}$ \\
\hline G2 (VA) & 12 & 3 & $25.0^{\mathrm{ab}}$ & 5 & $41.7^{c}$ & 2 & $16.7^{\mathrm{bc}}$ & 11 & $83.4^{\mathrm{b}}$ \\
\hline G3 $\left(\mathrm{AD}_{3} \mathrm{E}\right)$ & 12 & 4 & $33.3^{a}$ & 6 & $50.0^{\mathrm{bc}}$ & 1 & $8.30^{c}$ & 11 & $91.6^{\mathrm{ab}}$ \\
\hline $\mathrm{G} 4(\mathrm{Se})$ & 12 & 2 & $16.7^{b}$ & 8 & $66.7^{a}$ & 2 & $16.7^{\mathrm{bc}}$ & 12 & $100^{a}$ \\
\hline G5 (VC) & 12 & 3 & $25.0^{\mathrm{ab}}$ & 7 & $58.3^{b}$ & 2 & $16.7^{\mathrm{bc}}$ & 12 & $100^{a}$ \\
\hline G6 (Combin.) & 12 & 2 & $16.7^{\mathrm{b}}$ & 9 & $75.0^{a}$ & 1 & $8.3^{c}$ & 12 & $100^{a}$ \\
\hline
\end{tabular}

$a$ and b: Means denoted within the same column with different superscripts are significantly different at $P<0.05$. $N$ : total number of ewes in each group.

In sheep, there is a significant seasonal variation in the responsiveness of the hypothalamic-hypophysis axis to the negative feedback action of estrogen on LH secretion, which appears to be mainly dictated by the photoperiod (Herbison, 1995). During seasonal anestrus, LH continues to be released but with lower frequency than during the follicular phase of the cycle during the breeding season (Rosa and Bryant, 2003). The low level of estrogen was observed during seasonal anestrus, resulting in the short and long-term suppression of $\mathrm{GnRH}$ and gonadotrophin release (Clarke et al., 2009) and a marked change of hypothalamic responsiveness to estradiol alone can be observed (Webster and Haresign, 1983).

The transition from anestrus to reproductive activity is gradual with the occurrence of an initial short cycle as the first $C L$ regresses prematurely 5-6 days after its formation. It is only after the 1st ovarian cycle that behavioural estrus is exhibited (Rosa and Bryant, 2003). Estrogen is also responsible for estrous behaviour in all species including sheep; however, small amounts of progesterone priming are necessary for the induction of estrus in sheep during the first reproductive cycle of the breeding season (Herbison, 1995; Stellflug et al., 1997). Absence of ovulation during seasonal anestrus is thought to be due to reduced frequency of LH pulses (Wallace et al., 1986).

The beneficial effects of different treatments were pronounced on exhibiting estrous activity during transited period ewes. In particular ewes treated with vitamins $A$ or $\mathrm{AD}_{3} \mathrm{E}$. In accordance with the present results, Betacarotene supplementation positively affects ovarian activity in goats (Arellano-Rodriguez et al., 2007). Also, vitamin E-selenium injections given before mating significantly increased the incidence of estrus in ewes (Koyuncu and Yerlikaya, 2007).

\section{Progesterone (P4) profile:}

Data of P4 concentration in blood serum of ewes during different days post-mating (Table 6) showed significant $(P<0.05)$ increase in $P 4$ concentration with advancing post-mating day, being the highest on day 50 post-mating. This trend of increase was similar in all groups with similar P4 concentration in all groups at each sampling day. 
Table (6): Effect of treatment on progesterone concentration in serum of ewes at different days post- mating during breeding season.

\begin{tabular}{|l|c|c|c|c|}
\hline \multirow{2}{*}{$\begin{array}{c}\text { Treatment } \\
\text { group }\end{array}$} & $\mathbf{5}$ & $\mathbf{3 0}$ & $\mathbf{4 0}$ & $\mathbf{4 0}$ \\
\cline { 2 - 5 } & $\mathbf{5}$ & $\mathbf{3 0}($ Oont-mating (day) \\
\hline $\mathrm{G} 1($ Control) & $1.103 \pm 0.02^{\mathrm{d}}$ & $12.651 \pm 0.145^{\mathrm{c}}$ & $14.813 \pm 0.314^{\mathrm{b}}$ & $18.317 \pm 0.214^{\mathrm{a}}$ \\
\hline $\mathrm{G} 2(\mathrm{VA})$ & $1.313 \pm 0.01^{\mathrm{d}}$ & $12.632 \pm 0.278^{\mathrm{c}}$ & $14.212 \pm 0.242^{\mathrm{b}}$ & $18.738 \pm 0.252^{\mathrm{a}}$ \\
\hline $\mathrm{G} 3\left(\mathrm{AD} \mathrm{B}_{3} \mathrm{E}\right)$ & $1.214 \pm 0.05^{\mathrm{d}}$ & $12.264 \pm 0.124^{\mathrm{c}}$ & $14.333 \pm 0.258^{\mathrm{b}}$ & $18.812 \pm 0.334^{\mathrm{a}}$ \\
\hline $\mathrm{G} 4(\mathrm{Se})$ & $1.402 \pm 0.02^{\mathrm{d}}$ & $12.581 \pm 0.226^{\mathrm{c}}$ & $14.462 \pm 0.365^{\mathrm{b}}$ & $18.621 \pm 0.462^{\mathrm{a}}$ \\
\hline $\mathrm{G} 5(\mathrm{VC})$ & $1.211 \pm 0.03^{\mathrm{d}}$ & $12.862 \pm 0.157^{\mathrm{c}}$ & $14.126 \pm 0.275^{\mathrm{b}}$ & $18.701 \pm 0.341^{\mathrm{a}}$ \\
\hline $\mathrm{G} 6($ Combin.) & $1.121 \pm 0.05^{\mathrm{d}}$ & $12.131 \pm 0.148^{\mathrm{c}}$ & $14.135 \pm 0.285^{\mathrm{b}}$ & $18.562 \pm 0.225^{\mathrm{a}}$ \\
\hline
\end{tabular}

$a$ and $b$ : Means denoted within the same row with different superscripts are significantly different at $P<0.05$.

It was observed that $\mathrm{P} 4$ concentration was above $1 \mathrm{ng} / \mathrm{ml}$ starting from 5 days post-mating, which may indicate incidence of pregnancy or ovarian activity in term of presence of $\mathrm{CL}$ at this early period post-mating in all groups even in the control ewes.

The positive relationship between P4 level and post-insemination day confirmed the statement of Mukasa-Mugerwa and Viviani (1992), who recorded positive correlation between $\mathrm{P} 4$ levels and the gestation stage. They observed that $\mathrm{P} 4$ values on the $40^{\text {th }}$ day of pregnancy were higher than the peak values during the lutheal stage of the sexual cycle, which is due to an extraovarian source of progesterone (placental synthesis). Also, in support of this notion are the established significantly higher $(P<0.01) \quad P 4$ concentrations in pregnant vs. non-pregnant sheep. Also, Davies et al. (2006) found a positive correlation between the P4 levels and the surface of $C L$ in sheep with different ovulation values.

During seasonal anestrus, P4 levels remain virtually undetectable, while FSH concentrations do not seem to vary from those found during the breeding season. Although P4 levels are low and no gonadotrophin surge occurs, neither the ovary nor the hypothalamus are inactive. The LH pulse system, although active, is compromised as $\mathrm{GnRH}$ and $\mathrm{LH}$ pulse frequencies are low. The mature follicles present during anestrus are capable of producing estrogen which now has greater ability to suppress LH release. (Rosa and Bryant, 2003).

\section{Reproductive performance:}

The superiority of ewes in G6 treated with the combination treatment in term of estrous/mating rate during transit period and during breeding season (Table 7) was indicated also by expressing significantly $(P<0.05)$ the highest fertility rate $(100 \%)$, whereas all ewes in this group showed estrus, mated and lambed (Table 7).

Maximizing the fertility rate of ewes in G2 was associated with fecundity rate $(133 \%)$ and significantly $(P<0.05)$ higher prolificacy rate $(145 \%)$ than that of the other treated groups. Ewes in G2, G5 and G6 had the similar fertility rate $(91.67 \%)$, with significantly differences than G1, G3 and G4 (83.33, 75.0 and $75 \%$, respectively) and showed lower fecundity rate (92\%, $\mathrm{P} \geq 0.05)$ on $\mathrm{G} 4$ and lower prolificacy rate $(122 \%, \mathrm{P}<0.05)$ (Table 7$)$. 
It is worthy noting that ewes in $G 3$ and $G 4$ treated with vitamin $A_{3} E$ and Se showed similar fertility rate $(75 \%)$, and increased fecundity rate $(100 \%$ and $92 \% \mathrm{P} \geq 0.05)$ and prolificacy rate $(133$ and $122 \%, \mathrm{P}<0.05)$.

Table (7): Effect of treatment on reproductive traits of ewes during breeding season.

\begin{tabular}{|c|c|c|c|c|c|c|c|}
\hline Group & $N^{(1)}$ & \begin{tabular}{|c|} 
Mated \\
ewes
\end{tabular} & \begin{tabular}{|c|} 
Lambed \\
ewes $^{(2)}$
\end{tabular} & \begin{tabular}{|c|} 
Fertility \\
rate \%)(2/1)
\end{tabular} & \begin{tabular}{|c|} 
Born \\
lambs $^{(3)}$ \\
\end{tabular} & $\begin{array}{l}\text { Fecundity } \\
\text { rate }(\%)^{(3 / 1)}\end{array}$ & $\begin{array}{l}\text { Prolificacy } \\
\text { rate }(\%)^{(3 / 2)}\end{array}$ \\
\hline G1 (Control) & 12 & 12 & 10 & $83.33^{\mathrm{b}}$ & 15 & $125^{\mathrm{ab}}$ & $150^{\mathrm{a}}$ \\
\hline G2 (VA) & 12 & 11 & 11 & $91.67^{a}$ & 16 & $133^{a}$ & $145^{\mathrm{a}}$ \\
\hline $\mathrm{G} 3\left(\mathrm{AD}_{3} \mathrm{E}\right)$ & 12 & 11 & 9 & $75.00^{c}$ & 12 & $100^{\mathrm{bc}}$ & $133^{b}$ \\
\hline G4 (Se) & 12 & 9 & 9 & $75.00^{c}$ & 11 & $92^{c}$ & $122^{c}$ \\
\hline G5 (VC) & 12 & 12 & 11 & $91.67^{a}$ & 13 & $108^{b}$ & $118^{c}$ \\
\hline G6 Comb.) & 12 & 12 & 11 & $91.67^{a}$ & 13 & $108^{b}$ & $118^{c}$ \\
\hline
\end{tabular}

$a$ and b: Means denoted within the same column with different superscripts are significantly different at $\mathrm{P}<0.05$. $\mathrm{N}$ : total number of ewes in each group.

On the other hand, treatment of ewes in $\mathrm{G} 3\left(\mathrm{AD}_{3} \mathrm{E}\right)$ and $\mathrm{G} 4$ (Se) failed to increase fertility and fecundity rates compared with controls (G1) and other treatment groups, but significantly $(P<0.05)$ increased prolificacy rate as compared to that in G5 and G6. It is of interest to note that increasing prolificacy rate in G2 than in G6, inspit the nearly similar number of borns was attributed to increasing fertility rate in G6 than in G2 (Table 7).

The oxidative stress may occur at different sites, different times, and by different mechanisms in the animal system. Levels of the antioxidant vitamins are associated with fertility and production levels in ruminants including sheep. These antioxidants need to be replenished/regenerated or supplemented at appropriate timings in order to optimize the ruminant health and productive/reproductive performance (Nayyar and Jindal, 2010). The reactive oxygen species production during the oxidative stress is responsible for the ovarian pathology and uterine disorders affecting the female reproduction, with the poor fertility outcome (Qureshi et al. (2010). Also, antioxidant defenses in the female reproductive tract may have some regulatory role in fertility (Jean-François and Marc-André, 2001).

Activities of antioxidant enzymes, superoxide dismutase, nitric oxide synthase, glutathione reductase and glutathione-S-transferase in sheep CL are subjected to major changes during the estrous cycle (Al-Gubory et al., 2005). The mRNA expression and distribution of enzyme activities e.g. glutathione peroxidase, superoxide dismutase and catalase in the bovine oviduct during the estrous cycle indicated their physiological role in the events leading to successful fertilization and implantation in vivo (Jérôme and Jean-François, 2003).

The obtained enhancement of fertility of ewes in G6 may be attributed to the synergestic effects of the combined of differet vitamins and SE. The naturally occurring antioxidants: vitamin $E, \beta$-carotene and vitamin $C$ are known to ameliorate the oxidative stress generated during various physiological and pathological conditions (Nayyar and Jindal, 2010). Since vitamin C works in cooperation with other antioxidants, its administration in disease which are followed by oxidative stress is more effective when used in 
combined preparations. Qureshi et al. (2010) reported that with combined treatment of vitamin $\mathrm{C}+\mathrm{E}$ there was complete protection in the entire component of the ovaries and there was also significant increase in number of different types of developing follicles in deficient animals. Also, vitamin C has been associated with fertility in human and small range of other mammals (Millar 1992). Moreover, Se has been amply documented to significantly enhance animal development, a number of metabolic processes, and the reproductive success (Grela and Sembratowicz 1997). Administration of Se improves reproductive performance in ewes (Gabryszuk and Klewiec, 2002).

In agreement with the obtained improvement in fecundity rate of ewes in G2 treated with vitamin A, Arellano-Rodriguez et al. (2007) found that $\beta$-carotene supplementation, as a source of vitamin A, positively affects ovarian activity in goats. In this respect, there is feed dependent accumulation of $\beta$-carotene in bovine luteal tissue (Arikan and Rodway, 2001) and $\beta$-carotene is spread over the entire volume of luteal cells with higher levels occurring at distinct sites, including the surface (Arikan et al., 2002). Also, Vitamin E-selenium injections given before mating significantly increased fecundity rates in ewes (Koyuncu and Yerlikaya, 2007).

\section{Lambing performance:}

Sex ratio, type of births and mortality rate:

Results presented in Table 8 showed that the effect of treatment on sex ration and type of birth of produced lambs was significant $(P<0.05)$. Ewes G6 significantly $(P<0.05)$ produced more less males and more females (38.4:61.5\%).

Regarding the type of birth, ewes in G2 showed significantly $(P<0.05)$ the highest twin births and the lowest single type (62.5:37.5\%) versus an opposite trend in other treatment groups (G3-G6). However, the control ewes showed $50 \%$ for each type of birth (Table 8 ).

Table (8): Effect of treatment on sex ratio, type of birth and mortality rate of lambs.

\begin{tabular}{|c|c|c|c|c|c|c|}
\hline \multirow{2}{*}{$\begin{array}{c}\text { Treatment } \\
\text { group }\end{array}$} & \multirow{2}{*}{$\mathbf{N}$} & \multicolumn{2}{|c|}{ Born lambs } & \multicolumn{2}{|c|}{ Type of birth } & \multirow{2}{*}{$\begin{array}{l}\text { MR } \\
(\%)\end{array}$} \\
\hline & & $\mathbf{n}(\%)$ & $q^{\prime} \mathbf{n}(\%)$ & Single (\%) & Twine (\%) & \\
\hline G1 (Control) & 15 & $8(53.3)^{\mathrm{ab}}$ & $7(46.7)^{\mathrm{bc}}$ & $5(33.3)^{b}$ & $5(66.7)^{b}$ & 0.00 \\
\hline $\mathrm{G} 2(\mathrm{VA})$ & 16 & $8(50.0)^{b}$ & $8(50.0)^{b}$ & $6(37.5)^{b}$ & $5(62.5)^{\mathrm{a}}$ & 0.00 \\
\hline $\mathrm{G} 3\left(\mathrm{AD}_{3} \mathrm{E}\right)$ & 12 & $5(41.6)^{\mathrm{bc}}$ & $7(58.3)^{\mathrm{ab}}$ & $6(50.0)^{a b}$ & $3(50.0)^{c}$ & 8.33 \\
\hline G4 (Se) & 11 & $5(45.5)^{\mathrm{bc}}$ & $6(54.5)^{\mathrm{ab}}$ & $7(63.6)^{\mathrm{a}}$ & $2(36.4)^{\mathrm{cd}}$ & 9.09 \\
\hline G5 (VC) & 13 & $8(61.5)^{\mathrm{a}}$ & $5(38.4)^{c}$ & $9(69.2)^{a}$ & $2(30.8)^{d}$ & 7.69 \\
\hline G6(Combin.) & 13 & $5(38.4)^{\mathrm{c}}$ & $8(61.5)^{a}$ & $9(69.2)^{a}$ & $2(30.8)^{d}$ & 0.00 \\
\hline
\end{tabular}

$a$ and b: Means denoted within the same column with different superscripts are significantly different at $P<0.05$. N: Number of lambed ewes. MR (\%): Mortality rate.

It is of interest to note that mortality rate of produced lambs at weaning was $0 \%$ in $\mathrm{G} 1, \mathrm{G} 2$ and $\mathrm{G} 6$ versus $8.33,9.09$ and $7.69 \%$ in $\mathrm{G} 3, \mathrm{G} 4$ and G5, respectively (Table 7).

Lamb survival until weaning reflect milk production ability of ewes (Snowder and Glimp, 1991). The neonatal period is very decisive in the 
rearing of lambs and during this period, mortality is a major factor limiting profitability in sheep farming. Immediately after birth, lambs are characterized by homeostatic physiological variability, as shown in previous study on different physiologic parameters in these specie during the first 4 weeks postpartum (Piccione et al., 2006; Piccione et al., 2007).

Basser and Gay (1994) found that the mortality rate was lower in calves with a high than low serum immunoglobulin ( $\mathrm{lgG}$ ) concentration. Also, Solones et al. (1995) reported a higher mortality rate and lower serum immunoglobulin concentration in lambs fed artificial colostrum compared to those fed maternal colostrum. Colostrum is an important source of lgG, which is 100 -fold higher in colostrum than that in normal milk.

\section{Live body weight of lambs:}

Concerning LBW of lambs, data presented in Table (9) showed that the differences in average LBW of lambs at lambing between all treatment groups and the control one were not significant, but the differences were recorded between treatment groups. Lambs in G4, G5 and G6 were significantly heavier than those in G2 and G3. However, the differences in average LBW of lambs among groups based on sex and type of birth at lambing or weaning were not significant (Table 9).

In general, lamb body weight gains until weaning reflect milk production ability of their dams (Snowder and Glimp, 1991). It was reported that $\mathrm{Se}$ is transported to the offspring (lambs) along two pathways: via the placenta during the foetal stage, and with the colostrum at the neonatal phase. Selenium, even at low concentration in the ewe's body, is efficiently passed on to the foetus (Koller et al. 1984). Also, Cuesta et al. (1995) found that parenteral administration of Se significantly increases its concentrations in the colostrum and milk.

According to some authors (Horton, et al. 1986), Se improves health and increases body weight of the neonatal lambs. This was proved in lambs of ewes treated with Se alone (G4) or Se in combination with vitamins $A$, $\mathrm{AD}_{3} \mathrm{E}$ and $\mathrm{C}$ (G6). Also, Mauka et al. (1998) demonstrated the blood serum Se content in the sheep fed Se+vitamins-enriched feed to be by $25 \%$ higher (increase from 0.51 to $0.63 \mu \mathrm{mol} / \mathrm{l}$ ), the increase in the liver amounting to $35 \%$. The Se level increase was translated into lamb body weight gains: in month 5 of the experiment, the treatment lamb body weight was by $28.6 \%$ higher than that of the untreated lambs. Moreover, administration of Se improved daily weight gain of lambs (Gabryszuk and Klewiec, 2002) and vitamin E-selenium injections given before mating significantly increased lamb body weight at 60 days of age (Koyuncu and Yerlikaya, 2007). 
Table (9): Effect of treatment on average live body weight $(\mathrm{kg})$ of lambs at lambing and weaning.

\begin{tabular}{|c|c|c|c|c|c|c|}
\hline & $\begin{array}{c}\text { G1 } \\
\text { (Cont.) }\end{array}$ & $\begin{array}{c}\text { G2 } \\
\text { (VA) }\end{array}$ & $\begin{array}{c}\mathrm{G3} \\
\left(\mathrm{AD}_{3} \mathrm{E}\right)\end{array}$ & $\begin{array}{c}\mathrm{G} 4 \\
(\mathrm{Se}) \\
\end{array}$ & $\begin{array}{c}\text { G5 } \\
\text { (VC) }\end{array}$ & $\begin{array}{c}\text { G6 } \\
\text { Combin. }\end{array}$ \\
\hline \multicolumn{7}{|c|}{ Average LBW (kg) of total born lambs: } \\
\hline At lambing & $\begin{array}{l}3.10^{\mathrm{a}} \\
\pm 0.20\end{array}$ & $\begin{array}{l}2.96^{\mathrm{ab}} \\
\pm 0.16\end{array}$ & $\begin{array}{l}2.77^{\mathrm{b}} \\
\pm 0.21\end{array}$ & $\begin{array}{l}3.50^{\mathrm{a}} \\
\pm 0.25\end{array}$ & $\begin{array}{l}3.19^{a} \\
\pm 0.16\end{array}$ & $\begin{array}{l}3.26^{\mathrm{a}} \\
\pm 0.28\end{array}$ \\
\hline At weaning & $\begin{array}{l}15.73 \\
\pm 0.95\end{array}$ & $\begin{array}{l}14.16 \\
\pm 0.97\end{array}$ & $\begin{array}{r}15.27 \\
\pm 1.20\end{array}$ & $\begin{array}{r}16.87 \\
\pm 0.51\end{array}$ & $\begin{array}{r}16.46 \\
\pm 1.07\end{array}$ & $\begin{array}{r}14.67 \\
\pm 1.11\end{array}$ \\
\hline \multicolumn{7}{|c|}{ Average LBW (kg) of ram lambs: } \\
\hline At lambing & $\begin{array}{c}3.25 \\
\pm 0.28\end{array}$ & $\begin{array}{c}3.23 \\
\pm 0.00\end{array}$ & $\begin{array}{c}3.40 \\
\pm 0.24\end{array}$ & $\begin{array}{r}3.62 \\
\pm 0.37\end{array}$ & $\begin{array}{l}3.31 \\
\pm 0.26\end{array}$ & $\begin{array}{l}3.30 \\
\pm 0.48\end{array}$ \\
\hline At weaning & $\begin{array}{r}15.75 \\
\pm 1.35 \\
\end{array}$ & $\begin{array}{r}14.50 \\
\pm 1.65 \\
\end{array}$ & $\begin{array}{r}17.40 \\
\pm 1.24 \\
\end{array}$ & $\begin{array}{r}17.75 \\
\pm 0.70 \\
\end{array}$ & $\begin{array}{r}17.40 \\
\pm 1.65 \\
\end{array}$ & $\begin{array}{l}15.37 \\
\pm 1.01 \\
\end{array}$ \\
\hline \multicolumn{7}{|c|}{ Average LBW (kg) of ewe lambs: } \\
\hline At lambing & $\begin{array}{c}2.92 \\
\pm 0.29\end{array}$ & $\begin{array}{c}2.70 \\
\pm 0.23\end{array}$ & $\begin{array}{r}2.25 \\
\pm 0.11\end{array}$ & $\begin{array}{r}3.37 \\
\pm 0.37\end{array}$ & $\begin{array}{r}3.00 \\
\pm 0.00\end{array}$ & $\begin{array}{r}3.25 \\
\pm 0.36 \\
\end{array}$ \\
\hline At weaning & $\begin{array}{r}15.71 \\
\pm 1.45 \\
\end{array}$ & $\begin{array}{l}14.00 \\
\pm 1.28 \\
\end{array}$ & $\begin{array}{r}13.50 \\
\pm 1.70 \\
\end{array}$ & $\begin{array}{l}16.00 \\
\pm 0.70 \\
\end{array}$ & $\begin{array}{r}15.87 \\
+1.65 \\
\end{array}$ & $\begin{array}{l}13.25 \\
\pm 2.80 \\
\end{array}$ \\
\hline \multicolumn{7}{|c|}{ Average LBW (kg) of single lambs: } \\
\hline At lambing & $\begin{array}{c}3.14 \\
\pm 0.12 \\
\end{array}$ & $\begin{array}{c}3.53 \\
\pm 0.15 \\
\end{array}$ & $\begin{array}{c}3.24 \\
\pm 0.11 \\
\end{array}$ & $\begin{array}{r}3.16 \\
\pm 0.14\end{array}$ & $\begin{array}{c}3.01 \\
\pm 0.14\end{array}$ & $\begin{array}{c}3.37 \\
\pm 0.12 \\
\end{array}$ \\
\hline At weaning & $\begin{array}{l}16.00 \\
\pm 1.81\end{array}$ & $\begin{array}{l}16.66 \\
\pm 185\end{array}$ & $\begin{array}{r}17.40 \\
\pm 1.24\end{array}$ & $\begin{array}{l}16.83 \\
\pm 0.47\end{array}$ & $\begin{array}{r}16.88 \\
\pm 1.39\end{array}$ & $\begin{array}{r}17.60 \\
\pm 1.02\end{array}$ \\
\hline \multicolumn{7}{|c|}{ Average LBW (kg) of twin lambs: } \\
\hline At lambing & $\begin{array}{c}2.14 \\
\pm 0.23\end{array}$ & $\begin{array}{c}2.39 \\
\pm 0.22\end{array}$ & $\begin{array}{l}2.10 \\
\pm 0.12\end{array}$ & $\begin{array}{c}2.04 \\
\pm 0.10\end{array}$ & $\begin{array}{l}2.11 \\
\pm 0.11\end{array}$ & $\begin{array}{c}2.12 \\
\pm 0.14\end{array}$ \\
\hline At weaning & $\begin{array}{l}14.60 \\
\pm 1.18 \\
\end{array}$ & $\begin{array}{l}13.33 \\
\pm 1.07\end{array}$ & $\begin{array}{l}13.50 \\
\pm 1.70\end{array}$ & $\begin{array}{l}15.00 \\
\pm 2.00\end{array}$ & $\begin{array}{l}14.50 \\
\pm 1.65\end{array}$ & $\begin{array}{l}12.57 \\
\pm 1.28\end{array}$ \\
\hline
\end{tabular}

$a$ and $b$ : Means denoted within the same row with different superscripts are significantly different at $\mathrm{P}<0.05$.

\section{Blood parameters of lambs:}

Results presented in Table 10 showed that the effect of treatment on some blood biochemicals in blood serum of produced lambs was significant $(P<0.05)$. Briefly, lambs of $G 6$ showed significantly $(P<0.05)$ the highest concentration of total proteins, albumin and globulin versus the lowest values in lambs of the control group and moderate values in other treatment groups (G2-G5), being significantly $(P<0.05)$ higher than those of the control group and lower than those of $G 6$. Cholesterol concentration significantly $(P<0.05)$ increased in G6 and G2 as compared to the controls, being significantly higher in $\mathrm{G} 6$ than in $\mathrm{G} 2$.

Table (10): Effect of treatment on some blood biochemicals in serum of ewes at weaning.

\begin{tabular}{|c|c|c|c|c|}
\hline Treatment & $\begin{array}{c}\text { Total proteins } \\
(\mathrm{g} / \mathrm{dl})\end{array}$ & Albumin (g/dl) & Globulin (g/dl) & $\begin{array}{c}\text { Cholesterol } \\
\text { (mg/dl) }\end{array}$ \\
\hline G1 (control) & $6.15 \pm 0.02^{\mathrm{c}}$ & $2.809 \pm 0.002^{b}$ & $3.809 \pm 0.002^{b}$ & $62.0 \pm 0.70^{\mathrm{C}}$ \\
\hline G2 (VA) & $6.94 \pm 0.09^{b}$ & $2.906 \pm 0.002^{b}$ & $3.906 \pm 0.002^{b}$ & $67.0 \pm 0.70^{\mathrm{b}}$ \\
\hline $\mathrm{G} 3\left(\mathrm{AD}_{3} \mathrm{E}\right)$ & $6.82 \pm 0.13^{b}$ & $2.905 \pm 0.001^{b}$ & $3.905 \pm 0.001^{b}$ & $64.2 \pm 0.37^{c}$ \\
\hline $\mathrm{G} 4(\mathrm{Se})$ & $6.62 \pm 0.21^{b}$ & $2.905 \pm 0.002^{b}$ & $3.937 \pm 0.031^{b}$ & $65.6 \pm 0.92^{\mathrm{bc}}$ \\
\hline G5 (VC) & $6.88 \pm 0.04^{b}$ & $2.902 \pm 0.001^{b}$ & $3.903 \pm 0.001^{b}$ & $64.0 \pm 0.70^{c}$ \\
\hline G6(combin.) & $7.66 \pm 0.08^{a}$ & $3.232 \pm 0.182^{\mathrm{a}}$ & $4.200 \pm 0.192^{\mathrm{a}}$ & $77.8 \pm 0.37^{a}$ \\
\hline
\end{tabular}
different at $P<0.05$. 
Determining concentrations of blood total proteins is more practical and more economical for measuring animal immunity. There is a close relationship between serum total protein concentrations and serum $\lg G$ concentrations (Donovan et al. 1986). Concentrations of plasma total proteins and globulin can be used as an indicator for monitoring passive transfer and estimating the amount of circulating IgG in newborns. In addition, total protein concentrations in serum and colostrum are important for lamb growth (O'Brien and Sherman, 1993). Based on these findings, increasing concentration of albumin and globulin, and consequently total proteins in lambs of ewes (G6) may indicate high immunity and high tolerance of different stress factors, reflecting high viability of lambs in G6.

According to Piccione et al. (2011) the albumin's medium half-life ranged from 14 to 16 days in ruminants, after which period the liver is responsible for albumin synthesis (Thrall, 2004). Therefore, increasing albumin level in lambs of $\mathrm{G} 6$ indicated high liver function and good healthy status of these lambs. These results could be explained by the first intake of colostrum during the first hours of life of lambs. It is well demonstrated that newborn physiological protein concentration and globulin fractions are variable during the first month of life as adaptive response to various environmental factors after birth, including nutrition. In particular, the levels of these parameters are closely related to newborn ingestion of colostrum within the first hours of life (Piccione et al., 2009).

Bornez et al. (2009) reported an increase in concentration of total proteins and albumin in blood serum of lambs with the advanced age. This finding indicated high total protein content in lambs of G6 after birth as a result of increasing serum immunoglobulin content (Baranowski et al., 2000). Also, the higher cholesterol concentration in lambs of G6 may reflect the degree of stress (Schaffer et al., 1981). Therefore, lower cholesterol might be expected from stress (particularly by weaning lambs) in lambs of other groups.

\section{CONCLUSION}

Treatment of ewes prior to breeding September breeding season with antioxidant such as vitamins $\left(A, A_{3} E\right.$ or $\left.C\right)$, selenium or their combination had impact on lamb and milk production during breeding season, with the best results for ewes treated with vitamin $\mathrm{A}$.

\section{REFERENCES}

Agarwal, A.; Gupta, S. and Sikka, S. (2006). The role of free radicals and antioxidants in reproduction. Curr. Opin. Obstet. Gynecol., 18: 325-332.

Al-Gubory, K.H.; Bolifraud, P.; Germain, G.; Nicole, A. and Ceballos-Picot, I. (2004). Antioxidant enzymatic defence systems in sheep corpus luteum throughout pregnancy. Reproduction. 128: 767-774.

Al-Gubory, KH; Ceballos-Picot, I; Nicole, A; Bolifraud, P; Germain, G; Michaud, M; Mayeur, C and Blachier, F (2005). Changes in activities of 
superoxide dismutase, nitric oxide synthase, glutathione-dependent enzymes and the incidence of apoptosis in sheep corpus luteum during the estrous cycle. Biochim. Biophys. Acta. 1725: 348-357.

AOAC (1990). Official methods of analysis, $10^{\text {th }}$ ed. Association of Official Analytical Chemists. Washington DC.

Arellano-Rodriguez, G; Meza-Herrera, CA; Rodriguez-Martinez, R; Velazquez-Mendez, G; Mellado, M; Salinas, H; Perez-Razo, MA and Sanchez, F (2007). Short-term betacarotene supplementation positively affects ovarian follicular development and ovulation rate in goats. J. Appl. Anim. Res., 32: 1-4.

Arellano-Rodriguez, G.; Meza-Herrera, C.A.; Rodriguez-Martinez, R.; Dionisio-Tapia, R.; Hallford, D.M.; Mellado, M. and Gonzalez-Bulnes, A. (2008). Short-term intake of $\beta$ - carotene-supplemented diets enhance ovarian function and progesterone synthesis in goats. J. Anim. Physiol. Anim. Nutr., 93: 710-715.

Arikan, S and Rodway, RG (2001). Seasonal variation in bovine luteal concentrations of $\beta$ - carotene. Turk. J. Anim. Sci., 25: 165-168.

Arikan, S; Sands, HS; Rodway, RG and Batchelder, DN (2002). Raman spectroscopy and imaging of beta-carotene in live corpus luteum cells. Anim. Reprod. Sci., 71: 249- 266.

Aurousseau, B.; Gruffat, D. and Durand, D. (2006). Gestation linked radical oxygen species fluxes and vitamins and trace mineral deficiencies in the ruminant. Reprod. Nutr. Dev., 46: 601-620.

Baranowski, P.; Baranow-Baranowski, S. and Klata, W. (2000): Some haematological and biochemical serum and bone tissu indices of lambs derived from ewes fed on vitamin- and mineral-vitamin supplements during pregnancy. Bull. Vet. Inst. Pulawy., 44: 204-214

Basser, T.E., Gay, C.C., 1994. The importance of colostrum to the health of the neonatal calf. Vet. Clin. North Amer. Food Anim. Prac. 10, 107-117.

Bojanic, S. ; Lake R.; Place J.; Jones L.; Laycoock J.; Carter G. and AlaghBand-Zadeh, J. (1991). Serum progesterone concentration is raised during early follicular phase in women with polycystic ovaries. Ann. Clin. Biochem., 28: 105-106.

Bornez, R. ; Linares, M. B. and Vergara, H. (2009): Haematological, hormonal and biochemical parameters in lamb: Effect of age and blood sampling time. Liv. Sci., 121: 200-206.

Cardellino, R.A. and M.E. Benson (2002). Lactation curves of commercial ewes rearing lambs. J. Anim. Sci. 80:23-27.

Clarke I. J.; Qi Y.; Puspita Sari I.; Smith J. T. (2009). Evidence that RF-amide related peptides are inhibitors of reproduction in mammals. Front. Neuroendocrinol. 30, 371-378.

Cuesta, P. A.; McDowell, L.R.; Kunkle, W.E.; Wilkinson, N.S.; Martin, F.G. (1995). Effects of high-dose preparatum injections of Se and vitamin $E$ on milk and serum concentrations in ewes. Small Ruminant Research $18: 99-103$.

Cusack, P.M.V. ; McMeniman, N.P. and Lean, I.J. (2005). The physiological and production effects of increased dietary intake of vitamins $E$ and $C$ 
in feedlot cattle challenged with bovine herpesvirus 1. J. Anim. Sci., 83: 2423-2433.

Davies, K. L.; Bartlewski, P. M. ; Pierson R. L. and Rawlings N. C. (2006). Computer assisted image analyses of corpora lutea in relation to peripheral concentrations of progesterone: A comparison between breeds of sheep with different ovulation rates. Animal Reproduction Science, 96, No 1 $\square 2,165 \square 175$.

Donovan, G.A., Badinga, L., Collier, R.J., Wilcox, C.J., Braun, R.K. (1986). Factors influencing passive transfer in dairy calves. J. Dairy Sci., 69: 754-759.

Finkel, T. and Holbrook, N.J. (2000). Oxidants, oxidative stress and the biology of ageing. Nature. 408: 239-247.

Gabryszuk, M. and Klewiec, J. (2002). Effect of injecting 2- and 3-year-old ewes with selenium and selenium-vitamin $E$ on reproduction and rearing of lambs. Small Rumin. Res. 43:127-132.

Grela, E.R. and Sembratowicz I. (1997). Organiczne zwiazki selenu w zywieniu zwierzat [Organic selenium compounds in animal feeding], Med. Wet., 53, 385-386.

Guérin, P.; El Mouatassim, S. and Ménézo, Y. (2001). Oxidative stress and protection against reactive oxygen species in the preimplantation embryo and its surroundings. Hum. Reprod. Update. 7: 175-189.

Hamdon HAM (2005). productive and reproductive traits of Chios and Farafra sheep under subtropical Egyptian conditions. Ph.D. Thesis. Faculty of Agriculture Assiut University, Egypt.

Henry, E. J. (1964). Calorimetric determination of total protein. Clin. Chem. Principles and Technics. Harper Row NY, pp. 181.

Hill, P. G. and T. N. Wells (1983). Ann. Clin Biochem., 20: 265.

Herbison, A.E., 1995. Neurochemical identity of neurons expressing oestrogen and androgen receptors in sheep hypothalamus. J. Reprod. Fertil. Suppl. 49, 271-283.

Horton, S.A . and McCarthy, F.D. (1986). Use of injectable vitamin E and selenium-vitamin $E$ emulsion in ewes and suckling lambs to prevent nutritional muscular dystrophy. J. Anim. Sci., 62 :497-508.

Jainudeen, M. R. and E. S. E. Hafez (1993). Sheep and goats. In : Reproduction in Farm Animals. E.S.E. Hafez (Ed.) pp. 330-342. Lea and Febiger, Philadelphia, USA.

Jean-François, B. and Marc-André, S. (2001). Levels of enzymatic antioxidant defenses are modulated in the bovine oviductal fluid during the estrous cycle. 34th annual meeting of society for the study of reproduction. Jul. 28-Aug. 1, University of Ottawa. Abstract No. 562 Parent Session: Female Reproductive System (uterus/oviduct).

Jérôme, L. and Jean-François, B. (2003). Antioxidant defenses are modulated in the cow oviduct during the estrous cycle. Biol. Reprod., 68: 1157-1164.

Koller, L.D.; Whitbeck, G.A.; South, P.J. (1984). Trans-placental transfer and colostrums concentrations of selenium in beef cattle. Am. J. Vet. Res. $45: 2507-2510$. 
Koyuncu, M. and Yerlikaya, H. (2007). Effect of selenium-vitamin E injections of ewes on reproduction and growth of their lambs. S. Afr. J. Anim. Sci., 37: 233-236.

Lesser, M.P. (2006). Oxidative stress in marine environments: biochemistry and physiological ecology. Ann. Rev. Physiol., 68: 253-278.

Mauka, J.; Bronicki, M.; Debinski, Z. (1998). Profilaktyczne aspekty stosowania preparatu Nutril-Se (Lek Ljubljana) w odchowie jagniat [Prophylactic aspects of applying Nutril-Se (Lek Ljubljana) in lamb rearing], Zycie Wet.73: 26-27.

McDowell, L.R. (2002). Recent advances in minerals and vitamins on nutrition of lactating cows. Pak. J. Nutr., 1: 8-19.

McDowell, L.R.; Wilkinson, N.; Madison, R. and Felix, T. (2007). Vitamins and minerals functioning as antioxidants with supplementation considerations. Florida Ruminant Nutrition Symposium. Best Western Gateway Grand. Gainesville, FL, 30-31 January. http://dairy.ifas. ufl.edu/files/ rns/2007/ Mcdowell.pdf.Google

Millar, J. (1992). Vitamin C - the primate fertility factor? Med Hypotheses;38:292-295

Morsy, A.H.A. (2002). Evaluation of prolific and non-prolific breeds of sheep under the environmental condition of middle Egypt. Ph.D. Thesis, Faculty of Agriculture, El-Minia University.

Mukasa-Mugerwa, E. and Viviani, P. (1992). Progesterone concentrations in peripheral plasma of Menz sheep during gestation and parturition. Small Ruminant Rescue, 8, 47ロ53.

Nayyar, S. and Jindal, R. (2010). Essentiality of antioxidant vitamins for ruminants in relation to stress and reproduction. Iranian Journal of Veterinary Research, Shiraz University, Vol. 11, No. 1, Ser. No. 30: 1 9.

NRC (2001). National Research Council. Nutrient Requirement of Domestic Animals. Nutrient Requirements of Sheep. National Academy of Science, Washington, D.C., USA

O'Brien, J.P. and Sherman, D.M. (1993). Field methods for estimating serum immunglobulin concentrations in newborn kids. Small Rumin. Res., 11: 79-84.

Özawa, M; Tabayashi, D; Latief, TA; Shimizu, T; Oshima, I and Kanai, Y (2005). Alterations in follicular dynamics and steroidogenic abilities induced by heat stress during follicular recruitment in goats. Reproduction. 129: 621-630.

Piccione, G. ; Borruso, M.; Fazio, F. ; Giannetto, C.; Caola, G. (2007). Physiological parameters in lambs during the first 30 days postpartum. Small Anim. Sci. 72, 57-60.

Piccione, G., Casella, S., Giannetto, C., Vazzana, I., Niutta, P.P., Giudice, E., (2009). Influence of age on profile of serum proteins in the calf. Acta Vet. 59, 413-422.

Piccione, G. ; Costa, A. ; Bertolucci, C. ; Borruso, M. ; Pennisi, P. ; Caola, G., (2006). Acidbase balance modifications in the lamb and goat kids during the first week of life. Small Rumin. Res. 63, 304-308. 
Piccione, G., Scianò, S., Messina, V., Casella, S., Zumbo, A., (2011). Change in serum total proteins, proteins fractions and albumin-globulin ratio during neonatal period in goat kids and their mothers after parturition. Ann. Anim. Sci. 11, 251-260.

Qureshi, N., Sharma, R., Mogra, S. and Panwar, K. (2010). Amelioration of lead induced alterations in ovary of Swiss mice, by antioxidant vitamins. J Herbal Med Toxicol, 4(1):89-95.

Riley, J.C. and Behrman, H.R. (1991). Oxygen radicals and reactive oxygen species in reproduction. Proc. Soc. Exp. Biol. Med., 198: 781-791.

Rizzo, A.; Minoia, G.; Trisolini, C.; Manca, R. and Sciorsci, R.L. (2007). Concentrations of free radicals and beta-endorphins in repeat breeder cows. Anim. Reprod. Sci., 100: 257-263.

Rolschlau, P. (1974). Klin. Biochem. 12: 226.

Rosa, H.J.D. and Bryant, M.J. (2003). Seasonality of reproduction in sheep. Small Ruminant Research 48:155-171.

Roth, Z. (2008). Heat stress, the follicle, and its enclosed oocyte: mechanisms and potential strategies to improve fertility in dairy cows. Reprod. Domest. Anim., 43: 238-244.

Ruder, E.H.; Hartman, T.J.; Blumberg, J. and Goldman, M.B. (2008). Oxidative stress and antioxidants: exposure and impact on female fertility. Hum. Reprod. Update. 14: 345-357.

Sathya, A.; Prabhakar, S.; Sangha, S.P. and Ghuman, S.P. (2007). Vitamin E and selenium supplementation reduces plasma cortisol and oxidative stress in dystocia-affected buffaloes. Vet. Res. Commun., 31: 809-818.

Shaffer L., Roussel J. D., Koonce K. L. (1981). Effects of Age, TemperatureSeason, and Breed on Blood Characteristics of Dairy Cattle. J. Dairy Sci., 64: 62-70.

Snowder, G. D., and Glimp, H. A. (1991). Influence of breed, number of suckling lambs, and stage of lactation on ewe milk production and lamb growth under range conditions. J. Anim. Sci.69: 923-930

Solones, D., Such, X., Caja, G. (1995). Efecto de la utilizacion de un calostro concentro comercial sobre el crecimiento y la supervivencia de corderos immunudeprimidos. ITEA, 16: 735-737.

Stellflug J.N. ; Weems Y.S. and Weems C.W. (1997). Clinical reproductive physiology of ewes. Pp 594-598. In: Currebt Therapy in Large Animal Theriogenology. Youngquist R.S. ed. W.B. Saunders, Philadelphia.

SPSS (2004). SPSS for windows. Release 13.0. Standard version. Copyright SPSS Inc.

Thrall, M.A. (2004). Laboratory evaluation of plasma and serum proteins, in: Veterinary hematology and clinical chemistry. (Ed.) Lippincott Williams and Wilkins, Philadelphia, USA, pp. 401-515.

Treacher, T. T. (1978). The effects on milk production of the number of lambs suckled and age, parity and size of ewes. European Association for Animal Production Publication 23:31-35.

Wallace JM, McNeilly AS, Baird DT. Induction of ovulation during anoestrus in two breeds of sheep with multiple injections of $\mathrm{LH}$ alone or in combination with FSH. Journal of Endocrinology111:181-190. 
Webster, G.M. and Haresign, W. (1983) Seasonal changes in LH and prolactin concentrations in ewes of two breeds Journal of Reproduction and Fertility 67: 465-471.

Zaken, V.; Kohen, R. and Ornoy, A. (2000). The development of antioxidant defense mechanism in young rat embryos in vivo and in vitro. Early Preg., 4: 110-123.

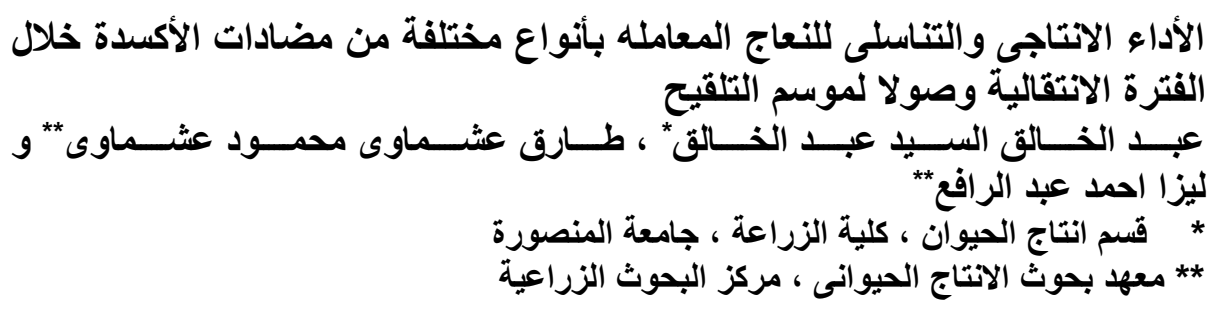

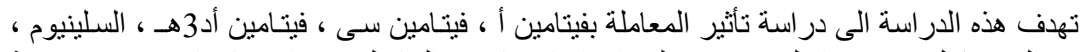

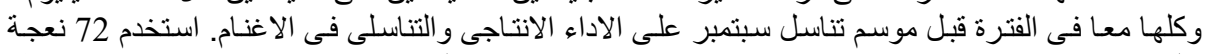

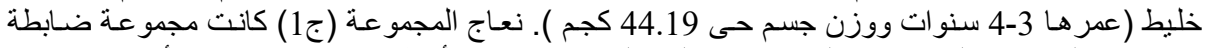

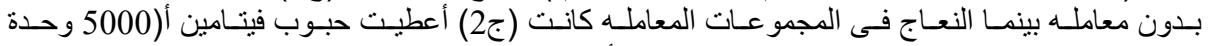

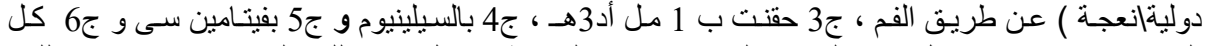

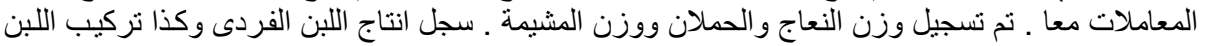

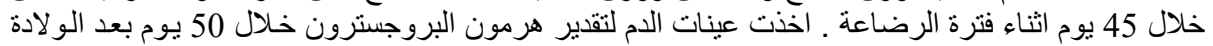

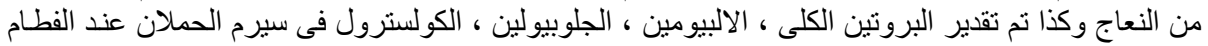

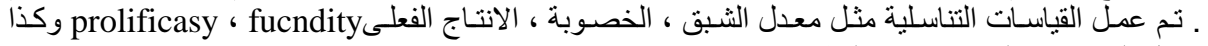

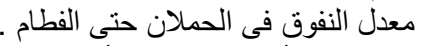

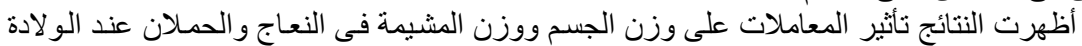

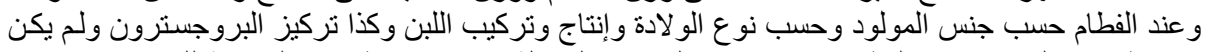

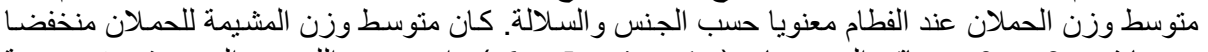

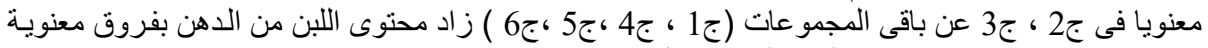

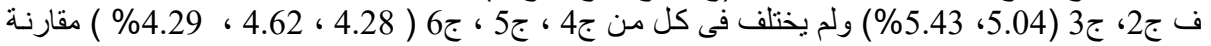

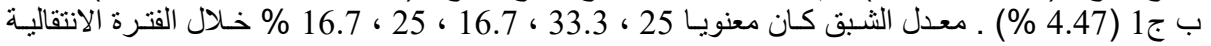

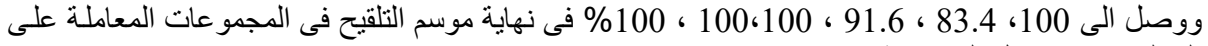

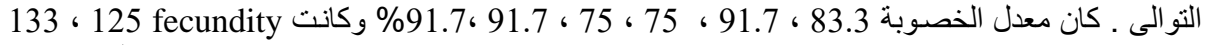

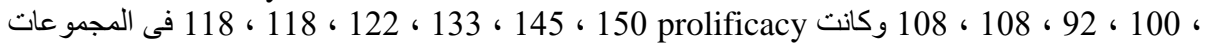

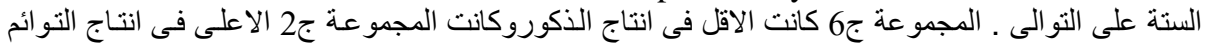

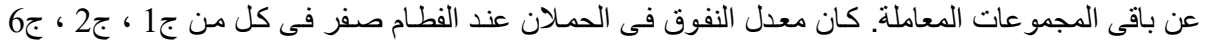

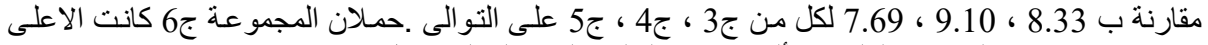

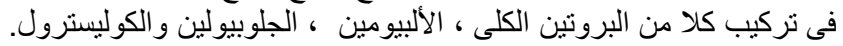

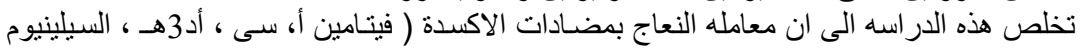

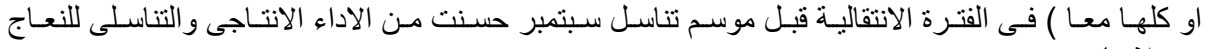

كلية الزراعة - جامعة المنصورة مركز البحوث الزراعية
قام بتحكيم البحث

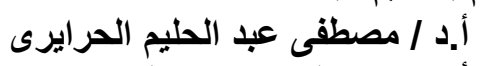
أ.د / بدير السيد اسماعيل 